\section{Agency for the Prohibition of Nuclear Weapons in Latin America and the Caribbean (OPANAL)}

The Agency (Organismo para la Proscripción de las Armas Nucleares en la América Latina y el Caribe) was established following the Cuban missile crisis to guarantee implementation of the world's first Nuclear-Weapon-Free-Zone (NWFZ) in the region. Created by the Treaty of Tlatelolco (1967), OPANAL is an inter-governmental agency responsible for ensuring that the requirements of the Treaty are enforced. OPANAL has played a major role in establishing other NWFZs throughout the world.

Organization. The Agency consists of three main bodies: the General Conference which meets for biennial sessions and special sessions when deemed necessary; the Council of OPANAL consisting of five member states which meet every two months plus special meetings when necessary; and the Secretariat General.

Members of the Treaty. Antigua and Barbuda, Argentina, Bahamas, Barbados, Belize, Bolivia, Brazil, Chile, Colombia, Costa Rica, Cuba, Dominica, Dominican Republic, Ecuador, El Salvador, Grenada, Guatemala, Guyana, Haiti, Honduras, Jamaica, Mexico, Nicaragua, Panama, Paraguay, Peru, St Kitts and Nevis, St Lucia, St Vincent and the Grenadines, Suriname, Trinidad and Tobago, Uruguay, Venezuela.

Headquarters: Schiller No. 326, 5th Floor, Col. Chapultepec Morales, México, D. F. 11570, Mexico.

Website: http://www.opanal.org

Email:info@opanal.org

Secretary-General: Edmundo Vargas Carreño (Chile).

\section{Andean Community}

On 26 May 1969 an agreement was signed by Bolivia, Chile, Colombia, Ecuador and Peru establishing the Cartagena Agreement (also referred to as the Andean Pact or the Andean Group). Chile withdrew from the Group in 1976. Venezuela, which was actively involved, did not sign the agreement until 1973. In 1997 Peru announced its withdrawal for five years. In 2006 Venezuela left as a result of Colombia and Peru signing bilateral trade agreements with the USA.

The Andean Free Trade Area came into effect on 1 Feb. 1993 as the first step towards the creation of a common market. Bolivia, Colombia, Ecuador and Peru have fully liberalized their trade. A Common External Tariff for imports from third countries has been in effect since 1 Feb. 1995.

In March 1996 at the Group's 8th summit in Trujillo in Peru, the then member countries (Bolivia, Colombia, Ecuador, Peru, Venezuela) set up the Andean Community, to promote greater economic, commercial and political integration between member countries under a new Andean Integration System (SAI).

The member countries and bodies of the Andean Integration System are working to establish an Andean Common Market and to implement a Common Foreign Policy, a social agenda, a Community policy on border integration, and policies for achieving joint macroeconomic targets.

Organization. The Andean Presidential Council, composed of the presidents of the member states, is the highest-level body of the Andean Integration System (SAI). The Commission and the Andean Council of Foreign Ministers are legislative bodies.
The General Secretariat is the executive body and the Andean Parliament is the deliberative body of the SAI. The Court of Justice, which began operating in 1984, resolves disputes between members and interprets legislation. The SAI has other institutions: Andean Development Corporation (CAF), Latin American Reserve Fund (FLAR), Simon Bolivar Andean University, Andean Business Advisory Council, Andean Labour Advisory Council and various Social Agreements.

Further to the treaty signed by 12 South American countries in May 2008, it is anticipated that the Andean Community will gradually be integrated into the new Union of South American Nations.

Official language: Spanish.

Headquarters: Avda Paseo de la República 3895, San Isidro,

Lima 17, Peru.

Website: http://www.comunidadandina.org

Email: contacto@comunidadandina.org

Secretary-General: Freddy Ehlers (Ecuador).

\section{Association of Caribbean States (ACS)}

The Convention establishing the ACS was signed on 24 July 1994 in Cartagena de Indias, Colombia, with the aim of promoting consultation, co-operation and concerted action among all the countries of the Caribbean, comprising 25 full member states and three associate members. A total of eight other non-independent Caribbean countries are eligible for associate membership.

Members. Antigua and Barbuda, Bahamas, Barbados, Belize, Colombia, Costa Rica, Cuba, Dominica, Dominican Republic, El Salvador, Grenada, Guatemala, Guyana, Haiti, Honduras, Jamaica, Mexico, Nicaragua, Panama, St Kitts and Nevis, St Lucia, St Vincent and the Grenadines, Suriname, Trinidad and Tobago, Venezuela.

Associate members. Aruba, France (on behalf of French Guiana, Guadeloupe and Martinique), the Netherlands Antilles and the Turks and Caicos Islands.

The CARICOM Secretariat, the Latin American Economic System (SELA), the Central American Integration System (SICA) and the Permanent Secretariat of the General Treaty on Central American Economic Integration (SIECA) were declared Founding Observers of the ACS in 1996. The United Nations Economic Commission for Latin America and the Caribbean (ECLAC) and the Caribbean Tourism Organization (CTO) were admitted as Founding Observers in 2000 and 2001 respectively.

Functions. The objectives of the ACS are enshrined in the Convention and are based on the following: the strengthening of the regional co-operation and integration process, with a view to creating an enhanced economic space in the region; preserving the environmental integrity of the Caribbean Sea which is regarded as the common patrimony of the peoples of the region; and promoting the sustainable development of the Greater Caribbean. Its current focal areas are trade, transport, sustainable tourism and natural disasters.

Organization. The main organs of the Association are the Ministerial Council and the Secretariat. There are Special Committees on: Trade Development and External Economic Relations; Sustainable Tourism; Transport; Natural Disasters; Budget and Administration. There is also a Council of National Representatives of the Special Fund responsible for overseeing resource mobilization efforts and project development. 